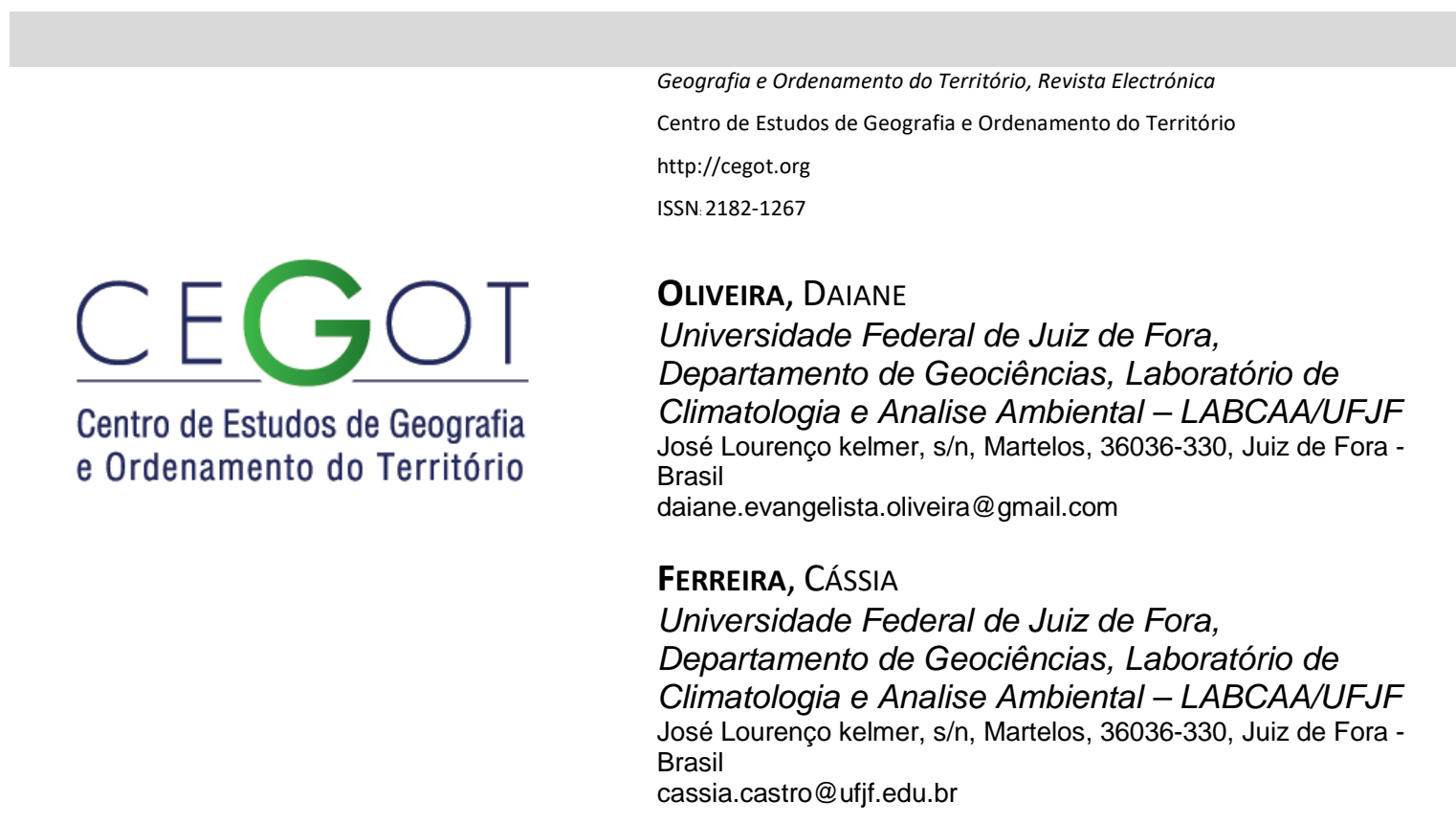

\title{
Aspectos climáticos da bacia hidrográfica do rio Preto - MG/RJ, Brasil, influência dos fatores geográficos na formação desse clima regional
}

The climatology of Preto river watershed - MG/RJ, Brazil, influence of geographical factors in formation of that regional climate

Referência: Oliveira, Daiane; Ferreira, Cássia (2017). Aspectos climáticos da bacia hidrográfica do rio Preto MG/RJ, Brasil, influência dos fatores geográficos na formação desse clima regional. Revista de Geografia e Ordenamento do Território (GOT), n.o 11 (junho). Centro de Estudos de Geografia e Ordenamento do Território, p. 283-307, dx.doi.org/10.17127/got/2017.11.013

\section{RESUMO}

Quando em 1979 Edmon Nimer lança seu livro "Climatologia do Brasil", um aparato para inúmeros trabalhos é lançado, dado que neste um catálogo com os principais tipos climáticos do país é apresentado. Posteriormente, novos autores e metodologias foram sendo adotadas, e o (re)conhecimento de climas cada vez mais específicos vai acontecendo. È partindo deste contexto e aproveitando dos SIG's para aquisição e manuseio dos dados, que a proposta deste estudo foi realizar um levantamento da climatologia da bacia hidrográfica do rio Preto - MG/RJ, através da relação da influência dos fatores geográficos na formação desse clima regional. Foram construídos mapas e produtos cartográficos. $\mathrm{E}$ como resultado constatou-se que a bacia se localiza em uma área de transição climática, havendo uma intrínseca relação entre o tempo e o ambiente.

Palavras-chave: clima regional; fatores geográficos; inventário climático; tipologias climáticas; 


\begin{abstract}
When in 1979 Edmon Nimer launches his book "Climatology in Brazil," a support for numerous works is released, since this a catalog with the main climatic types of the country is presented. Subsequently, new authors and methodologies have been adopted, and the knowledge of climates increasingly specific was happening. It is based on this context and taking advantage of GIS for the acquisition and handling of the data, the purpose of this study was to survey the climatology of the basin of the river Preto - MG / RJ, through the relationship of the influence of geographical factors in the formation of such regional climate . maps and cartographic products were built. And as a result it was found that the basin is located in a climate transition area, has be the intricical relathioship between the weather and the environment.
\end{abstract}

Keywords: regional climate; geographical factors; climatic inventory; climatic types.

\title{
1. Introdução
}

Tecendo um resgaste pela história do pensamento climatológico brasileiro, constata-se que esta se aporta em grande parte na meteorologia dinâmica, que é uma postura teórica e metodológica que remonta às décadas de 60 e 70, período onde havia muitas discussões acerca do resgate de uma dimensão sistêmica nas ciências em geral e, concomitantemente, na geografia. Muitos questionamentos e propostas teórico-metodológicas vinham surgindo e o enfoque dinâmico ganhava força nos trabalhos nas mais diversas ciências, o que refletiu em uma análise geográfica do clima que o entendesse em sua totalidade, levando em consideração a sucessão dos tipos de tempo, seu ritmo e duração.

É uma perspectiva que tem seus antecedentes atrelados a Escola de Bergen, preconizados pelo norueguês Vilhelm Bjerknes, e que tem como pressupostos relações e conceitos termohidrodinâmicas e a construção de cartas sinóticas. É uma perspectiva que possibilita uma melhor compreensão dos fenômenos atmosféricos, dado que leva em consideração a origem, frequência e trajetória das massas de ar e chega ao Brasil com os trabalhos de Max Sorre, que tem, ainda hoje, suas concepções norteando diversos trabalhos em climatologia (MONTEIRO, 1973; NIMER, 1979; SANT'ANNA NETO, 2005; MENDONÇA e DANNI-OLIVEIRA 2007; TARIFA, 1975; SETTE, 1996, 2000; dentre outros). 
Uma revolução paradigmática sobre os fenômenos climáticos se inicia, muito mais preocupada com as interconexões e as interdependências dos mais diversos fenômenos, e a concepção de um ambiente integrado passa a vigorar. Conforme destacam Mendonça e Danni-Oliveira (2007) e Sant'Anna Neto (2005), essa mudança paradigmática na meteorologia vai repercutir fortemente na geografia brasileira e trabalhos pioneiros, como os de Adalberto Serra e Leandro Ratisbona (1942, "Massas de ar na América do sul"), que se destacam pela inovação segundo a dinâmica das massas de ar, e mais tarde, os de Edmon Nimer (1979), com seu estudo da circulação atmosférica sul-americana, e os de Monteiro (1973), com seu paradigma de ritmo, se tornam as bases da climatologia brasileira.

Em seu livro "Climatologia do Brasil" Edmon Nimer (1979) faz um inventário dos climas do país. Sua obra descreve a relação entre o ambiente, a posição geográfica e a atmosfera, de tal modo que as principais características dos climas são ressaltadas. Esta, se torna referência nos estudos climáticos no Brasil, em especial aos de cunho regional. A partir daí, outros autores vão criando sínteses climáticas para as diversas regiões brasileiras, e o (re)conhecimento de climas cada vez mais específicos vão acontecendo.

Para a região Sudeste do Brasil, por exemplo, já foram realizados estudos por Sant'Anna Neto (2005) e em escalas maiores por Monteiro (1973), para o estado de São Paulo, e em cidades ou bacias hidrográficas, pesquisas por Ferreira (1997, 2002), Pellegatti e Galvani (2009), Fialho et al (2012), Silva (1996, 2001), Schneider (2014), Antunes (2015), entre outros. No entanto, ainda há a necessidade de uma maior investigação e resgate acerca do fenômeno climático em escala regional, uma vez que esta unidade espacial é importante na identificação, descrição e classificação de unidades climáticas regionais.

Tecendo um resgaste histórico constata-se que por algum tempo as outras escalas espaciais de análise para o estudo dos fenômenos climáticos tiveram preferência se comparadas com a regional. Em 2005, Sant'Anna Netto já destacava que desde os anos 70, quando Edmon Nimer (1979) propõe um estudo dos climas brasileiros, é que não mais se observa estudos de cunho regional. Tal fato pôde ser constatado por Ely (2006), quando em análise das monografias, dissertações e teses brasileiras, observou que poucos trabalhos utilizam esta escala como unidade espacial de análise. 
Um dos motivos que justificam o fato é que historicamente o intenso processo de urbanização que o país vivenciou a partir da década de 70, trouxe consigo os problemas de um crescimento sem grandes preocupações com as questões ambientais, fazendo com que se voltassem os olhos para os estudos do urbano no Brasil e, consequentemente, para os de cunho climático. Logo, a partir da década de 70 e principalmente na década de 90, ocorreu um aumento dos estudos de clima urbano. Também, a escassez de dados, atrelada as limitações no manuseio dos mesmos, fez com que as pesquisas nesta escala de abordagem do fenômeno climático fossem reduzidas.

Mas esse é um quadro que vem mudando e já nota-se está ocorrendo um retorno aos estudos regionais, uma vez que existem manifestações do clima que só podem ser observadas nesta escala. Ainda mais em um país com dimensões continentais como o Brasil, que apresenta inúmeros tipos climáticos (NIMER, 1979). Há a necessidade de se fazer estudos mais dinâmicos e que o relacione com as esferas do cotidiano e com o ambiente do qual faz parte. O clima enquanto ciência precisa ser repensado e suas relações com a sociedade em âmbito regional não podem ser reduzidas a apenas insumos do processo produtivo, ou manifestações classificatórias generalistas, uma vez que suas manifestações afetam a vida da sociedade em geral.

É neste contexo que, pautados na climatologia dinâmica e aproveitando das possibilidades que o atual período técnico-cientifico-informacional (SANTOS, 2014) dispõe, novos estudos passaram a ter a dimensão regional como unidade espacial. Estes estão atrelados principalmente as estimativas de temperatura do ar em relação aos alvos de cobertura da terra, como os de BARBOSA (2006) e PIMENTEL et al (2015), e em interpolação de dados de precipitação, como os de MELO JUNIOR (2003) e MARCUZZO et al (2011). Há ainda modelagens com fins de classificação climática.

O uso do geoprocessamento e da informática vem permitindo uma maior agilidade na aquisição e manuseio dos dados climáticos. A criação de sensores mais modernos e confiáveis, o uso de radares de imageamento e a utilização de Sistemas de Informação Geográfica (SIG's), são alguns dos ganhos que a ciência adquiriu e que se bem utilizados servirão para um maior (re)conhecimento das manifestações climáticas. Estes contribuem para a elaboração e/ou (re)formulação de sínteses sobre a dinâmica da natureza, na medida 
que agilizam o manuseio das informações, assim como possibilitam a modelagem dos sistemas ambientais.

Assim, dada a necessidade de conhecer o ambiente e as relações que nele ocorre, caracterizando o clima e aproveitando dos SIG's para aquisição e manuseio dos dados, que a proposta deste estudo foi realizar um levantamento da climatologia da bacia hidrográfica do rio Preto - MG/RJ, através da relação da influência dos fatores geográficos na formação desse clima regional.

\section{Referencial teórico}

Conforme destaca Ribeiro (1995, p.75) "qualquer estudo regional tem de começar pela análise dos elementos naturais" e com os estudos climáticos não seria diferente. Tempo e clima integram a realidade do espaço e em mútua interação sofrem influências do sítio onde se insere e a ele condicionam. "Os insumos climáticos, de ordem hierárquica superior são sempre redefinidos pela forma e pelo conteúdo do (no) espaço próximo à superfície da Terra" (TARIFA, 2002, p. 28).

A distribuição da radiação em escala local pode ser influenciada pela topografia, formas do terreno e pela orientação e inclinação das vertentes do mesmo. A temperatura por sua vez, sofrerá influência do padrão de cobertura que vem sendo dado a terra e da situação topográfica onde o sítio se insere. Em termos de precipitação pode-se destacar o efeito orográfico e os componentes adiabáticos de compressão e expansão nos volumes pluviométricos. E os efeitos da latitude podem ser simulados em pequenas escalas (MENDONÇA e DANNI-OLIVEIRA, 2007; NIMER, 1979). Também os processos genéticos serão responsáveis pelas várias unidades que podem ser encontradas, uma vez que o tempo está em constante (re)arranjo, se modificando em escalas espaciais e temporais.

É assim que o clima enquanto um "ambiente atmosférico constituído pela série de estados da atmosfera acima de um dado lugar em uma sucessão habitual" (SORRE, 1951, p. 13-14) segue as diversas combinações que caracterizam o tempo atmosférico, estabelecendo relações com a superfície terrestre e a sociedade, criando arranjos espaciais. Relações estas 
que são complexas e muito instáveis, e a interação entre a circulação atmosférica e os aspectos geográficos de uma determinada área (TAVARES, 2004) se torna a responsável pela variabilidade climática.

Mas se de um lado o clima sofre interferência do ambiente, de outro, ao mesmo influencia. O clima é considerado um regulador central, que influência direta ou indiretamente os fatores bióticos e abióticos, o que o coloca dentre os fatores fundamentais para explicar, prever e entender o crescimento e desenvolvimento dos recursos naturais. E como o mesmo é variável no espaço e no tempo, constitui num importante fator de mudança na superfície terrestre.

Desta forma, um estudo regional terá de realçar tais questões, dado que o clima é formado por interações (RIBEIRO, 1995). Cada atributo em determinada porção do espaço será, ou não, beneficiado pelas características do ambiente onde se está localizado e sobressairá (ou não) sobre os outros de acordo com suas especificidades, e com o clima não será diferente. Suas causas podem ser explicadas por um ou outro fator em específico, mas que reagindo uns com os outros formarão tipos climáticos distintos.

Conhecer as características do sítio e as relações que neste ocorre se torna, portanto, importante, dado que inúmeras combinações são encontradas e causas diversas podem ser as responsáveis pelos tipos climáticos. Seu (re)conhecimento torna possível aferir certas relações que não seriam em caso contrário, chegando a uma compreensão mais totalitária da espacialização das variáveis climáticas.

Tal postura está relacionada ao destacado por Nimer (1979), que ressalta que

a experiência tem-nos mostrado que nenhum fenômeno da natureza pode ser compreendido, quando encarado isoladamente, fora dos demais circundantes. Qualquer acontecimento natural pode ser convertido num contra-senso quando analisado fora das condições que o rodeiam, ao contrário, se considerado em ligação com os demais poderá ser compreendido e justificado (NIMER, 1979, p.9).

Os elementos climáticos sofrem influência dos padrões de controle, se reorganizam e se interligam entre si, variando de acordo com o contexto em que estão inseridos. Entre estes destacam-se a precipitação, a pressão atmosférica, a temperatura do ar, a umidade relativa do ar e os ventos, que se analisados em conjunto dão conta de identificar as condições climáticas de determinada área, pelo menos em um primeiro momento. 
Independentemente da ação humana, o clima difere-se de uma região para outra, ou até mesmo dentro de alguns poucos quilômetros. As variações em quantidade, intensidade e distribuição estacional de temperatura, precipitação, umidade, pressão atmosférica e ventos, associados às variáveis do local, vão produzir inúmeras situações e tipos climáticos diferentes. Tornando, importante obter mecanismos que nos permitam conhecer e identificar estas diferentes unidades climáticas em escala regional (FERREIRA, 2002, p.85).

E é neste contexto que, a partir de referenciais teóricos (NIMER, 1979; CAVALCANTI et al 2009), será apresentada a seguir uma metodologia de caracterização climática, buscando a todo momento tecer relações entre as diferentes manifestações dos atributos que compõem o espaço e que em suma permitiram uma análise mais totalitária do clima, à medida que considera todas as suas imbricações.

\section{Procedimentos metodológicos}

A metodologia foi conduzida baseada em grande parte no trabalho de Nimer (1979), o qual ressalta em sua obra os principais fatores de formação do clima do Sudeste do Brasil, e em outros procedimentos de construção e modelagem de sistemas ambientais (CHRISTOFOLETTI,1999; LANG e BLASCHKE, 2009; FERREIRA, 2014). A partir desses, o que se buscou foi a compreensão da climatologia da área de estudo, perpassando as várias escalas de abordagem do fenômeno climático. Tal postura se apoia na crença de que há uma estreita relação entre as manifestações climáticas e o ambiente.

Como a posição geográfica (mapa 1) influência na distribuição e regime dos elementos climáticos, em primeiro lugar, cabe ressaltar a localização e características gerais da área de estudo, uma vez que esta evidenciou uma pré-seleção das variáveis a serem levantadas. Esse procedimento metodológico deu subsídios à escolha de quais fatores geográficos são os que poderiam estar efetivamente influenciando os tipos climáticos da região. 


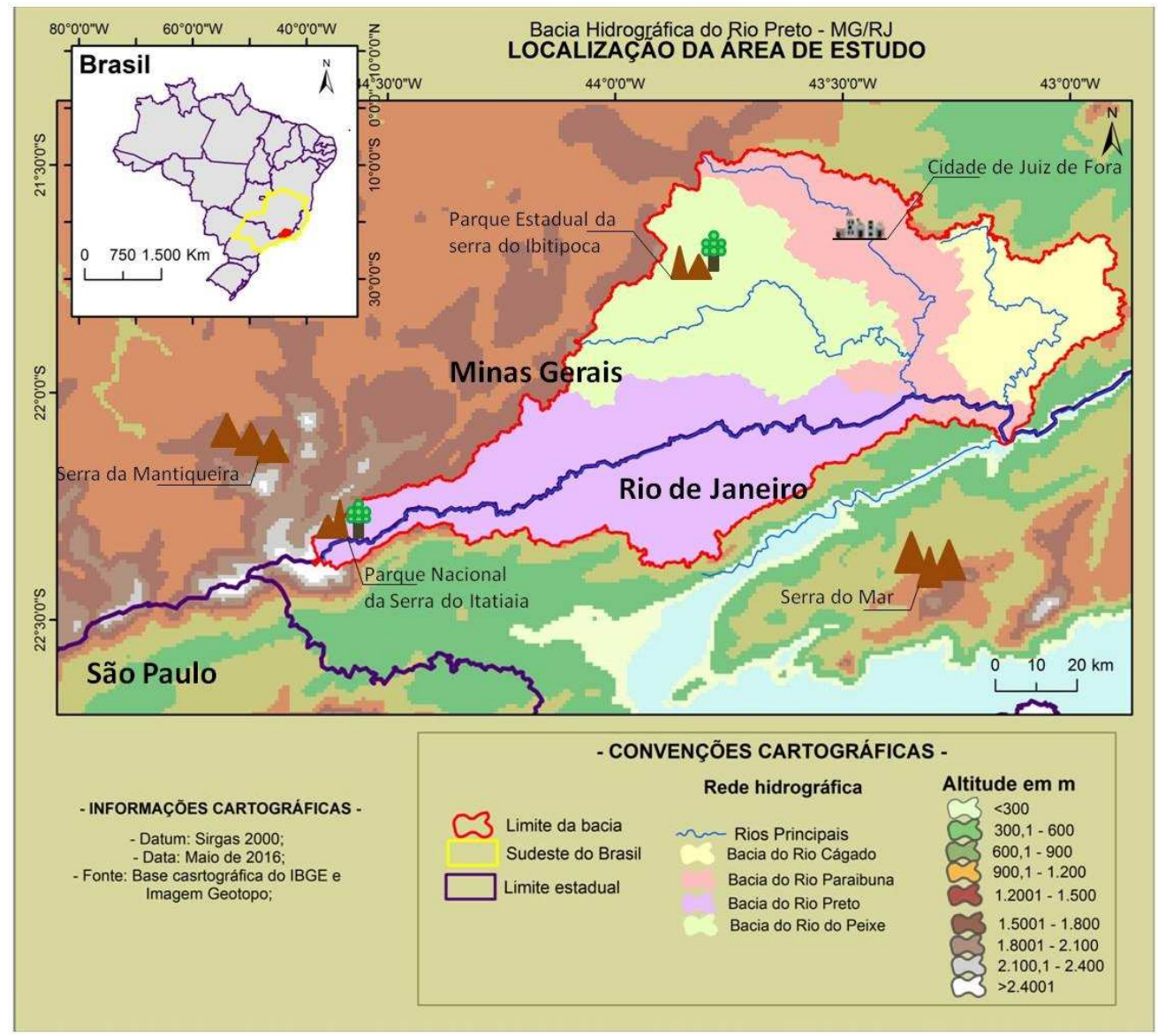

Mapa 1 - Localização da área de estudo.

A unidade espacial de estudo, representada pela bacia hidrográfica do Rio preto, está posicionada na zona da mata Mineira e terras Fluminenses adjacentes, no Noroeste do Estado do Rio de Janeiro e no Sudeste do Estado de Minas Gerais, a Centro-Oeste da Serra do Mar, em uma região denominada, segundo Ab'Saber (1970), como domínio morfoclimático dos "Mares de Morro" florestados. Engloba 37 municípios, dentre os quais 9 pertencentes ao Estado do Rio de Janeiro e 28 ao Estado de Minas Gerais. Ocupa uma área de cerca de $8.593 \mathrm{~km}^{2}$ e apresenta uma população de cerca de 5.259.067 habitantes (IBGE, 2010). É uma sub-bacia da bacia do rio Paraíba do Sul, a qual é pertencente da região hidrográfica da bacia do Atlântico Sudeste (ANA, 2013) e possui três rios principais como seus afluentes: o rio Paraibuna, o rio do Peixe e o rio Cágado. O rio Preto coincide com o limite entre os estados do Rio de Janeiro e Minas Gerais.

Partindo dessa sua posição geográfica é possível dizer que a área de estudo, em termos climáticos, sofreria influências de fatores dinâmicos e estáticos (NIMER, 1979). Os fatores dinâmicos são representados pela própria dinâmica da atmosfera, enquanto que os fatores 
estáticos são a morfologia do relevo e a posição em relação ao oceano. Juntos compõem este clima regional.

Quanto as conexões com os fatores estáticos, foi realizado um levantamento do quadro regional (posição geográfica, continentalidade/maritimidade, relevo e cobertura da terra), utilizando de modelos gerados a partir do uso do Geoprocessamento e do Sistema de Informação Geográfica (SIG). Escolheu-se trabalhar com esta metodologia dado que a área de estudo é extensa e a disponibilidade de dados escassa.

Todos os mapas foram confeccionados no software ArcGIS 10 e uma breve explanação da metodologia usada em cada um desses será destacada na tabela 1.

\begin{tabular}{|c|c|c|c|}
\hline Tema & Variável & Método / Ferramentas & Base de Dados \\
\hline \multirow{3}{*}{$\begin{array}{l}\text { Latitude/ } \\
\text { Longitude }\end{array}$} & $\begin{array}{l}\text { Posição } \\
\text { Geógrafica }\end{array}$ & \multirow{3}{*}{ Vetorização. } & $\begin{array}{l}\text { Cartas sinóticas da } \\
\text { marinha do Brasil. }\end{array}$ \\
\hline & Maritimidade & & $\begin{array}{l}\text { Base cartográfica do } \\
\text { IBGE. }\end{array}$ \\
\hline & Continentalidade & & \\
\hline \multirow{3}{*}{$\begin{array}{l}\text { Aspectos } \\
\text { do Relevo }\end{array}$} & Altitude & $\begin{array}{l}\text { Utilizou-se da ferramenta Tim Creat. Os } \\
\text { intervalos entre as curvas foram de } 20 \text { metros. }\end{array}$ & $\begin{array}{c}\text { Carta topográfica na } \\
\text { escala de 1:50.000, } \\
\text { Bases Cartográficas } \\
\text { Digitais (IBGE, 1983), } \\
\text { Imagens SRTM. }\end{array}$ \\
\hline & Declividade & $\begin{array}{l}\text { Utilizou-se da ferramenta Slope. Chegando-se } \\
\text { as seguintes classes: }<15 \% \text {, entre } 15 \%-30 \% \text {; } \\
\text { entre } 30 \%-45 \% \text { e }>45 \% \text {. }\end{array}$ & Imagens SRTM \\
\hline & $\begin{array}{l}\text { Orientação das } \\
\text { vertentes }\end{array}$ & $\begin{array}{l}\text { Utilizou-se da ferramenta surface. As classes } \\
\text { de orientação utilizadas foram os pontos } \\
\text { Cardeais (Norte, Sul, Leste, Oeste) e } \\
\text { Colaterais (Nordeste, Noroeste, Sudeste, } \\
\text { Sudoeste, Sudoeste (DE BIASI et al, } 1977 \\
\text { apud ARMANI, 2009). Adotou-se um esquema } \\
\text { de cores onde as cores quentes estariam } \\
\text { voltadas para Norte e as frias para Sul. }\end{array}$ & Imagem SRTM \\
\hline $\begin{array}{l}\text { Cobertura } \\
\text { da terra }\end{array}$ & $\begin{array}{l}\text { Cobertura da } \\
\text { terra }\end{array}$ & $\begin{array}{l}\text { Processamento da imagem, combinando as } \\
\text { bandas } 3,4 \text { e } 5 \text {. Edição, interpretação, } \\
\text { reclassificação e filtragem dos dados. }\end{array}$ & Imagem LANDSAT \\
\hline
\end{tabular}

Tabela 1 - Metodologias empregadas na confecção dos mapas.

Mas se por um lado o relevo, a latitude e a continentalidade explicam a distinção de ambientes,

as respostas só podem ser encontradas após o estudo dos fenômenos dinâmicos: massas de ar, anticiclone, frentes, ciclones, instabilidades tropicais, etc., cuja atuação, não apenas é maior ou menor para as diversas regiões como também sofre variação de intensidade no decorrer do ano em épocas diferentes para cada fenômeno. O relevo, a latitude e a continentalidade são fatores geográficos que complementam o fator mais importante - a circulação atmosférica (NIMER, 1979, p.30). 
Desta forma, outra etapa do trabalho consistiu na análise sinótica de superfície, com fins de observar e quantificar a participação dos sistemas atmosféricos na área de estudo. Para tal foram analisadas cartas sinóticas da marinha do Brasil (ano de 2006, tido como habitual) no horário das 12 horas, sendo este considerado o horario ideal, dado que a das 00 horas representariam o dia anterior ou posterior. Para garantir maior precisão nos dados, e porque a área de estudo tem dimensões regionais, optou-se por considerar como passível de ter influenciado no tempo todos os "mecanismos" que estivessem em atuação dentro de um quadrante que abrangesse as coordenadas geográficas 1500'00" S, 3000'00" $\mathrm{S}$, $30 \circ 00^{\prime} 00^{\prime \prime}$ O e 5000'00"O. Tais cartas são baseadas em campos de pressão atmosférica e permitem observar os sistemas frontais, as massas de ar, as ZCAS, assim como suas dinâmicas e trajetórias, o que permite aferir as tipologias de tempo que prevaleceram nos dias estudados e relacionar com os registros dos elementos meteorologicos em superficie,

Posteriormente, pautando-se na ideia de que a intrínseca relação clima-ambiente-sociedade cria arranjos espaciais, os quais são passiveis de serem identificados e mapeados, a terceira etapa do trabalho consistiu na realização de um levantamento dos aspectos climáticos da bacia hidrográfica, através do mapeamento das variáveis: temperatura, radiação e precipitação (tabela 2). Este, daria um indicativo da materialização e espacialização do clima na área de estudo.

\begin{tabular}{|c|c|c|c|}
\hline Tema & Variável & Método / Ferramentas & Base de Dados \\
\hline \multirow{2}{*}{$\begin{array}{c}\text { Aspectos } \\
\text { climáticos }\end{array}$} & Temperatura & $\begin{array}{c}\text { Utilizou-se de sensoriamento remoto termal para a } \\
\text { reclassificação dos tons de cinza da imagem, em } \\
\text { valores de temperatura aparente do solo. }\end{array}$ & $\begin{array}{c}\text { Banda termal do satélite } \\
\text { LANDSAT 8 }\end{array}$ \\
\cline { 2 - 4 } & Radiação & $\begin{array}{c}\text { Processamento da imagem, utilizando da } \\
\text { ferramenta Area Solar Radiation. }\end{array}$ & Imagens SRTM \\
\cline { 2 - 4 } & Precipitação & $\begin{array}{c}\text { Os dados pontuais foram espacializados à partir da } \\
\text { ferramenta de interpolação de dados IDW (Inverse } \\
\text { Distance Weighting). }\end{array}$ & $\begin{array}{c}\text { Dados mensais totais de } \\
\text { precipitação (INMET). } \\
\text { Referentes ao período } \\
\text { compreendido entre 1980- } \\
2010 .\end{array}$ \\
\hline
\end{tabular}

Tabela 2 - Metodologias empregadas na confecção dos mapas climáticos.

Por fim, considerando que existem escalas de abordagem do clima e que dependendo desta uma ou outra variável exercerá maior ou menor influência na formação das tipologias de tempo e diferenciações climáticas, a ressalva que se faz é que houve a preocupação em apresentar as características que descrevem a área de estudo perpassando ambas escalas de abordagem. Partindo-se do Zonal, uma vez que é o Sol a principal entrada de energia e principal diferenciador de áreas latitudinalmente, perpassando pelas influências de cunho 
regional, para assim chegar a uma caracterização da bacia hidrográfica do Rio Preto de fato, correlacionando, sempre que possível, todas as variáveis.

Após todos os mapeamentos iniciou-se o processo de análise dos resultados, buscando a todo momento ter uma visão dinâmica da realidade, onde uma caracterização geral do sitio se sobrepunha e completava a diferenciação climática. E foi com base nessas correlações que, por fim, fez-se um zoneamento das principais unidades climáticas que podem ser encontradas na bacia hidrográfica do rio Preto. A metodologia para a classificação das unidades utilizou como criterio de delimitação a sobreposição do layers para analise preliminar da interrelação entre os elementos climáticos e os fatores geograficos. Desta forma foi possivel observar as principais tipologias climaticas da área de estudo. Foi vinculado a cada uma unidade, uma breve descrição das caracteristicas gerais que dão sentido de unidade a elas, diferenciando-a das demais.

\section{Resultado e discussões}

Em termos zonais (mapa 2), é principalmente a posição geográfica, que imprime a bacia uma caracterização climática. A bacia hidrográfica se localiza em uma área de transição climática da região Sudeste do Brasil, mas o "caráter de transição climática da Região Sudeste se inclina mais para os climas tropicais do que para os temperados" (NIMER, 1979, p.275).

Sua localização na zona térmica Tropical (CONTI, 1989) faz com que sofra, influência da tropicalidade, apresentando uma entrada de energia superior às maiores latitudes. Com isso, tem-se que o balanço de radiação na área de estudo é maior que nas latitudes mais elevadas, uma vez que depende em grande parte da altura solar (NIMER, 1979). Este tipo de comportamento, torna os processos de evaporação e evapotranspiração mais ativos, o que é acentuado, na região, pela existência de superfícies liquidas, criando pré-condições às precipitações (CONTI, 1989).

A sazonalidade dos elementos climáticos é bem marcada e segue, em grande parte, o próprio movimento de translação. Tanto o balanço de radiação, quanto as precipitações, indicam a existência de duas estações bem diferenciadas, uma que vai de outubro a março, 
mais quente, chuvosa e irradiada; e uma que vai de abril a setembro, mais fria e seca. A média anual das precipitações gira em torno de $1536 \mathrm{~mm}$ anuais na bacia (ANA, Hidroweb) mas há pontos próximos à serra do Itatiaia, em que já foram registrados totais superiores aos 3500mm (1983). A amplitude térmica anual média está na faixa dos 5으 (NIMER, 1979). A disponibilidade hídrica local também é importante para acentuar esses contrastes, principalmente com a formação de chuvas convectivas no verão.

Há uma realidade climática onde ocorreram os encontros entre os sistemas extratropicais e os tropicais. A atuação predominante foi das massas de ar originárias sobre o oceano e uma pequena atuação das de origem continental pode ser observada (gráfico 1). Estas, ao seguirem suas trajetórias influenciam nos tipos de tempo, pois carregam consigo características de seu local de origem, o que ocasiona fortes mudanças regionais em termos climáticos, podendo gerar determinada instabilidade nos lugares por onde passam.

Para o ano de 2006, considerado habitual, a área foi caracterizada pela atuação mais frequente e predominante da Massa Tropical Atlântica (em 173 dos dias), seguida da Massa Polar Atlântica (em 104 dos dias) e dos sistemas frontais (em 39 dias). A atuação da Zona de Convergência do Atlântico Sul, importante fornecedor de umidade, foi um dos fatores responsáveis pelas precipitações no final da primavera e verão e foi constatada em 31 dos dias. Também foi registrada a presença de linhas de instabilidade atmosférica em 18 dias.

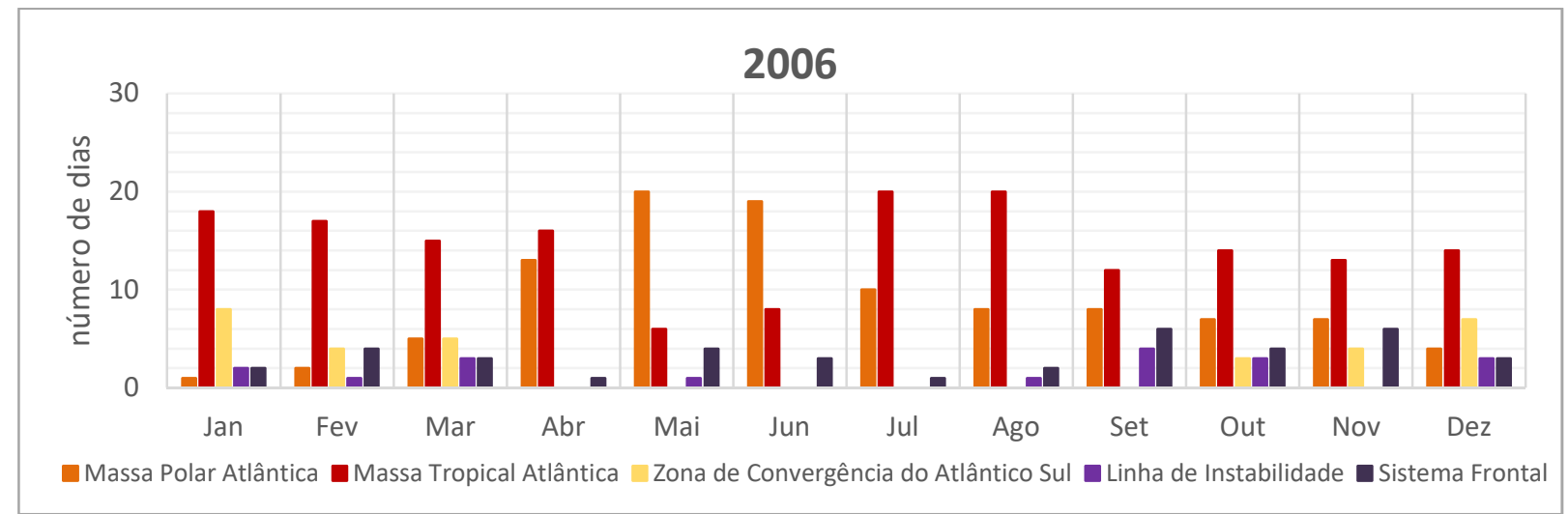

Gráfico 1 - Atuação dos sistemas atmosféricos.

Estes sistemas influenciam nas dinâmicas climáticas regionais, e atrelados à distância em relação aos oceanos e o próprio modelado do relevo (mapa 2), vão formando tipos climáticos distintos. A espacialização dos processos sinóticos na bacia esteve condicionada principalmente ao efeito orográfico que as variações topográficas (tanto regionais, quanto 
locais) exercem no direcionamento, velocidade e intensidade das massas, durante suas trajetórias.

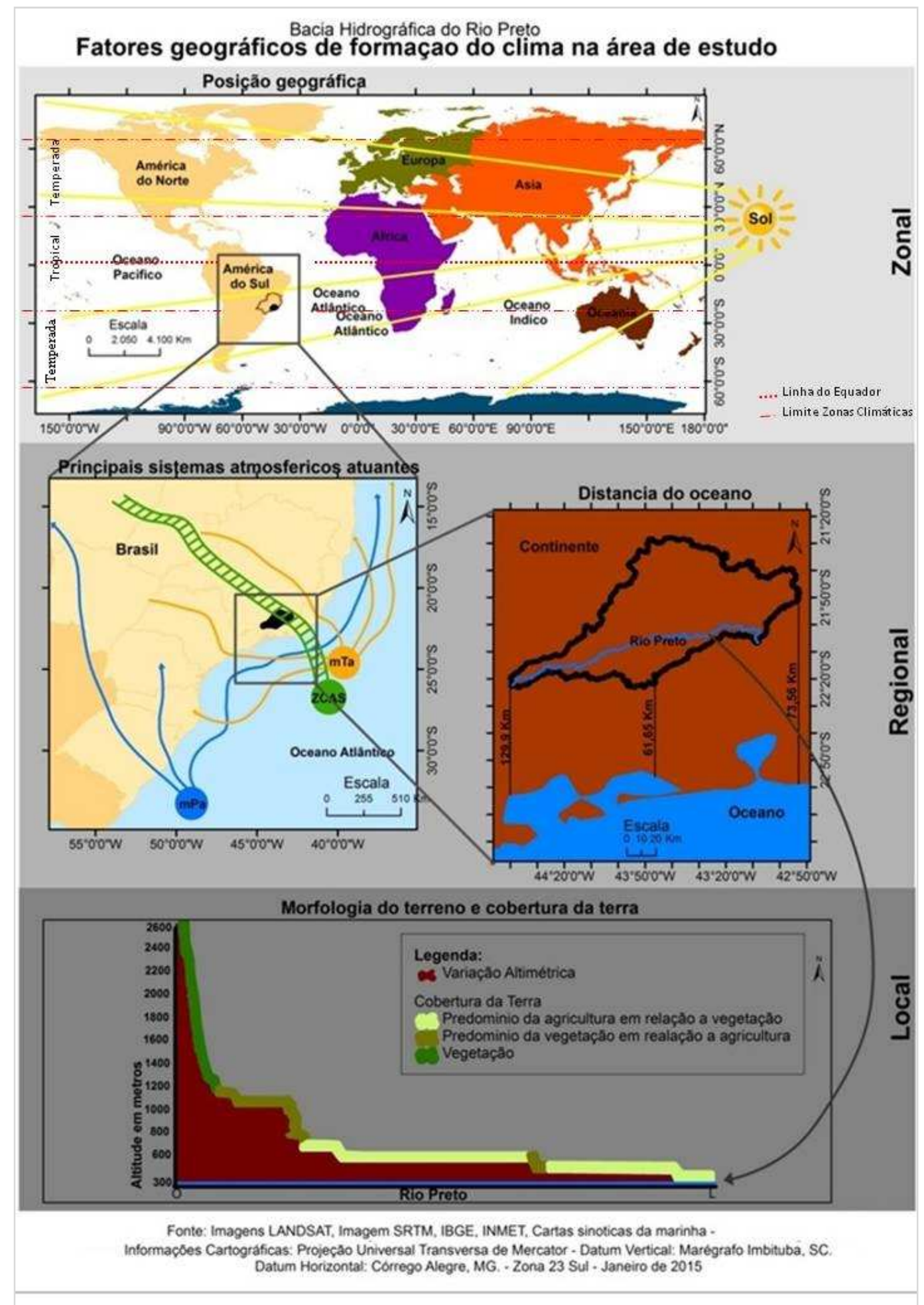

Mapa 2 - Principais fatores geográficos de formação do clima na área de estudo. Zonal: posição geografica nas zonas térmicas; Regional: atuação de sistemas atmosfericos e distancia (em linha reta) do oceano Atlântico; Local: Morfologia do terreno e cobertura da terra (transcecto correspondente ao rio Preto). 
O fato de a bacia se localizar próxima ao oceano Atlântico, precisa ser considerado sob dois aspectos, uma vez que a maritimidade influencia diretamente no clima. Em primeiro lugar que esta distância (em linha reta) variou entre $61,62 \mathrm{Km}$ e $129,9 \mathrm{Km}$ e que isso implicou em uma realidade climática caracterizada pela presença de massas de ar que ainda carregam muita umidade, e que consequentemente faz com se tenha volumes de precipitação que podem chegar aos $1000 \mathrm{~mm}$ e $3500 \mathrm{~mm}$ em anos tidos como úmidos.

Em segundo lugar que ao se deslocarem perpassam pela Serra do Mar, o que faz com que grande parte da umidade fique pelo caminho, devido aos mecanismos adiabáticos de compressão e dispersão e a formação das chuvas orográficas a barlavento. "Este caráter de sua topografia favorece as precipitações, uma vez que ela atua no sentindo de aumentar a turbulência do ar pela ascendência orográfica, notadamente durante a passagem de correntes perturbadoras, que em nossa área correspondem às frentes polares e as linhas de IT" (NIMER, 1979).

Em escala local foi a morfologia e a morfoestrtura do relevo, atreladas aos padrões de cobertura da terra, os principais diferenciadores de unidades climáticas na área de estudo. Em relação ao modelado do relevo (mapa 3), destaca-se que tanto a declividade, quanto as variações altimétricas e a orientação de suas vertentes, exerceram influência no clima regional e local da bacia. A distribuição da radiação em escala local foi influenciada pela topografia, formas do terreno e pela orientação e inclinação das vertentes do relevo. A temperatura por sua vez, sofreu influência do padrão de cobertura que vem sendo dado a terra e da situação topográfica onde o sítio se insere.

A parte mais elevada da bacia se localiza no maciço do Itatiaia, na Unidade Geomorfológica Planalto de Itatiaia (mapa 1), a Oeste e Sudoeste da bacia onde são encontradas altitudes que chegam aos 2400 metros. O que predominam na área de estudo são as altitudes entre 600 e 900 metros, correspondendo a cerca de $60 \%$ de seu total. Mesmo apresentando uma morfologia do terreno bastante movimentada, apresenta em sua maior parte declives inferiores a 30\%, sendo estes os que predominam nas áreas Sul, Norte e Leste. Estas são as áreas menos elevadas e por mais que em escala local possam apresentar uma ou outra feição com declividades mais acentuadas, na escala espacial de análise da imagem SRTM, não são percebidas. Onde são encontrados os maiores valores de altitude (acima de 
$1200 \mathrm{~m})$, constatou-se a existência de declividades superiores a $45 \%$. Estas áreas se encontram cobertas por vegetação.

Este tipo de modelado exerceu bastante influência quanto à recepção de radiação solar (mapa 4) dado que a disposição das faces das vertentes do relevo se posicionou de maneiras distintas. O que predominam são as vertentes voltadas para Sudeste (34\%) e Noroeste (27\%), o que permite aferir a existência de áreas menos sombreadas que outras, sendo às áreas voltadas para Noroeste as que recebem maior insolação, uma vez que dada a trajetória aparente do sol, descrevendo um arco no céu voltado para o Norte, em quase todo o ano, os terrenos com orientação da vertente voltados para Norte receberão mais radiação que os voltados para Sul. Assim, o fluxo de radiação que chega a uma vertente bastante inclinada e posicionada em direção Norte, em área Subtropical Austral, será mais intenso do que outra, com a mesma inclinação e no mesmo local, posicionada em direção Sul (LOMBARDO, 1996). Por este motivo "as orientações e declividades das vertentes tem uma importância significativa nas características dos topoclimas, com as vertentes N/NE se aquecendo mais que as S/SW" (ARMANI, 2009, p.2).

Esta configuração espacial da disposição das faces das vertentes do relevo está condicionada a uma tectônica regional, e está relacionada com a existência de um sistema de falhas estruturais na bacia. As bacias dos rios Paraibuna, Peixe e Preto representam a escarpa interior (vertente Norte) da Serra da Mantiqueira voltada para o vale do rio Paraíba do Sul, enquanto que a do rio Cágado representa um planalto com suave inclinação para Sul, até atingir o rio Paraibuna. Tal disposição espacial pode ser o que justifica o direcionamento dos sistemas atmosféricos na área de estudo, prevalecendo o direcionamento Sudoeste - Nordeste. 


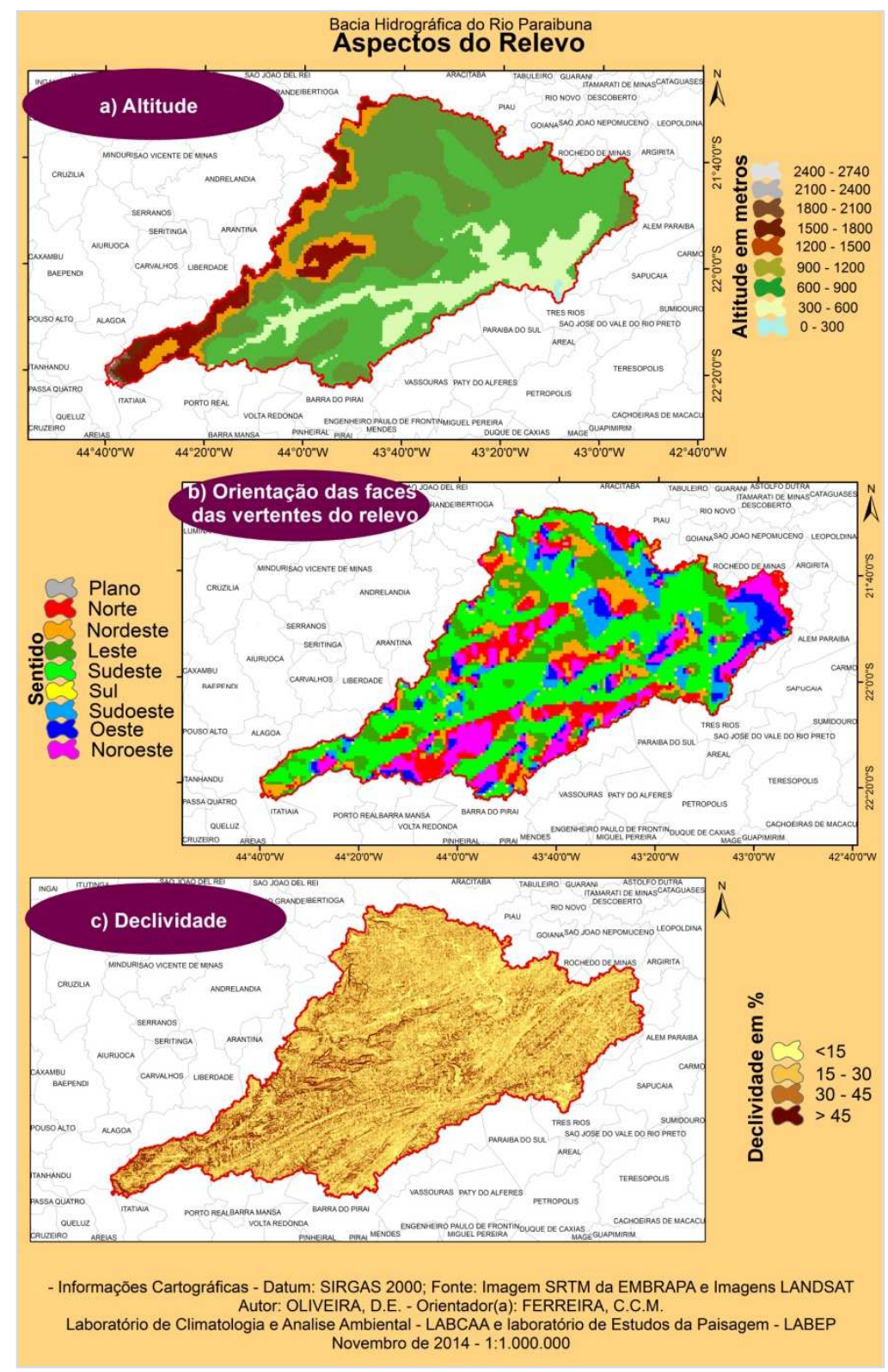

Mapa 3 - Aspectos do relevo.

A este atrela-se o fato de que "a orografia faz com que as vertentes situadas a barlavento apresentem totais de precipitação muito superiores aos apresentados pelas vertentes situadas a sotavento, constituintes de áreas de "sombra de chuvas" uma vez que ocasionam a ascensão da massa de ar, a sua saturação e a precipitação" (PELLEGATI e GALVANI, 2009). Influenciando a convecção do ar, provocada pelas altas temperaturas aliadas à forte umidade, favorecida pela presença da Mata Atlântica. 


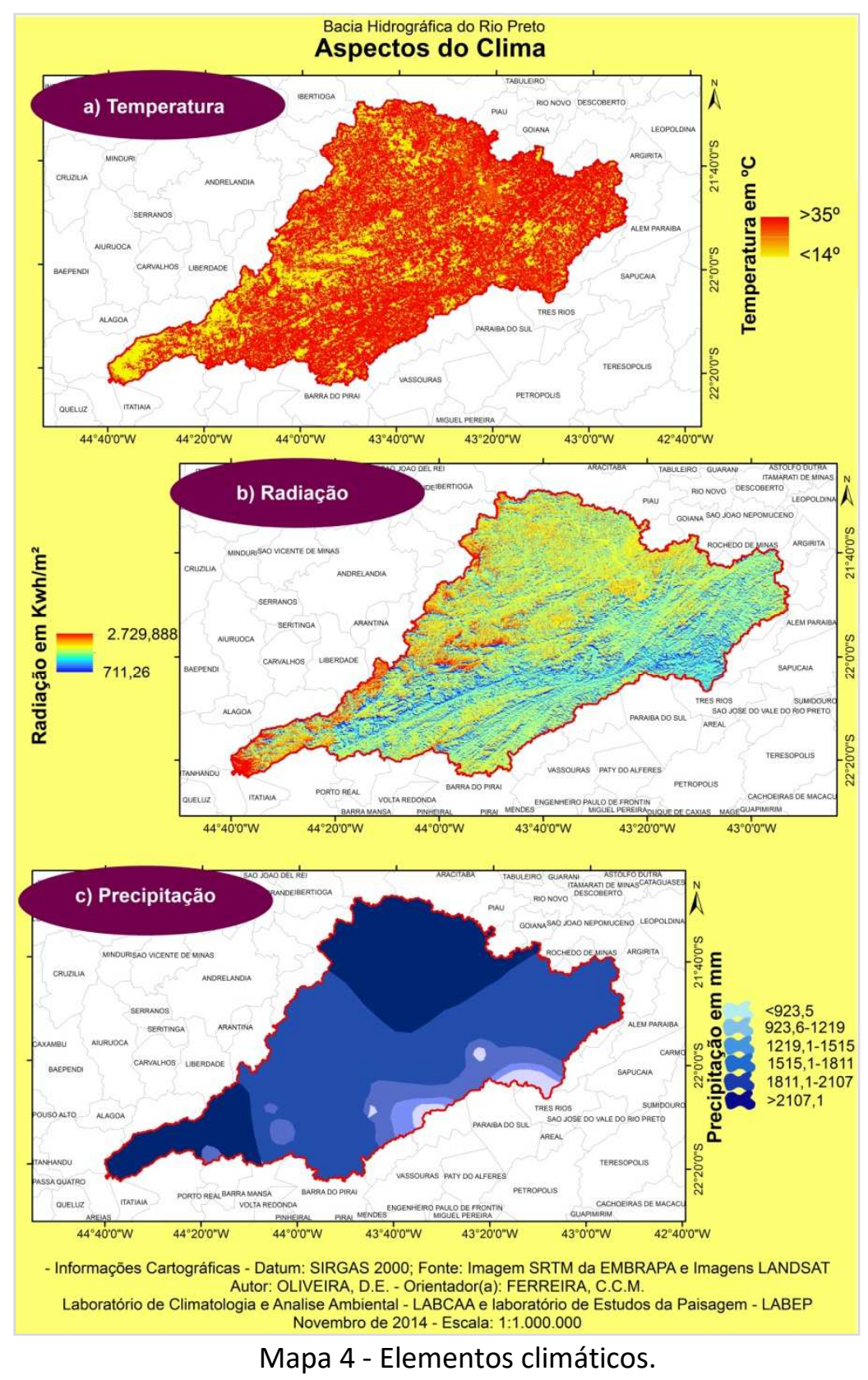

Ainda em relação ao balanço de radiação anual (mapa 4), constata-se que as áreas mais elevadas e com os maiores declives, à Sudoeste e Oeste, são as que apresentaram os maiores valores de radiação, indo de encontro ao fato de que áreas mais elevadas apresentariam maior incidência de radiação (BRASSEUR E SOLOMON, 1986), uma vez que sendo mais elevadas não se apresentariam, portanto, sombreadas por outros alinhamentos estruturais. Em contrapartida, nas áreas menos elevadas, localizadas a Sul da bacia e onde estão as calhas dos rios principais, foram registrados os menores índices de radiação, os 
quais chegaram ao máximo de $1.000 \mathrm{Kwh} / \mathrm{m}^{2}$, podendo estar sofrendo sombreamento por parte do conjunto morfoestrutural Mantiqueira Setentrional.

Nas áreas mais elevadas, apesar da incidência de radiação ser maior, constata-se que foram encontradas as menores temperaturas (menores que $14^{\circ} \mathrm{C}$ ), principalmente em Itatiaia. $\mathrm{O}$ fato é que com a elevação da altitude tem-se progressivamente uma diminuição da temperatura, dado à ação dos componentes adiabáticos de dispersão. "Como se pode concluir, embora o afastamento das influências marítimas e o aumento da latitude exerçam papel importante no comportamento das temperaturas mínimas, na Região Sudeste o mais importante é assumido pelo relevo" (NIMER, 1979, p.283).

Também a presença de cobertura vegetal densa e significativa, vem influenciando na diminuição destas temperaturas. "A relação entre vegetação e temperatura do ar se dá no controle da radiação solar, do vento e da umidade do ar. A vegetação também serve para reduzir a incidência de precipitação no solo e modifica a concentração da umidade na atmosfera e na superfície" (CARVALHO, 2001, p. 12). Há que se destacar ainda, que o fato de o relevo ser movimentado também acentuará as inversões térmicas.

Outra questão é que a morfoestrutura do relevo influencia na velocidade e direção dos ventos. Em áreas fechadas e abrigadas dos ventos as variações serão maiores que em áreas expostas aos ventos. As correntes de vento diminuem a velocidade quando entram em contato com as rugosidades da superfície. No entanto, deve-se ressaltar que há outros elementos que também influenciam.

Por sua vez, as maiores temperaturas $\left(>18{ }^{\circ} \mathrm{C}\right)$ foram encontradas na porção Norte e Nordeste da bacia, região que apresenta menor presença de vegetação e são menos elevadas. Também a presença da área urbana do município de Juiz de Fora (Estado de Minas Gerais) contribuiu para a elevação da temperatura nessa área (podendo chegar a $36^{\circ} \mathrm{C}$ ), à medida que vem criando um clima urbano específico que se difere de seu entorno rural. Sendo o mais populoso da Zona da Mata Mineira, representa $1 \%$ da cobertura da terra da bacia.

O tipo de morfologia do terreno também vem condicionando, padrões distintos de precipitação. Próximo a Serra de Itatiaia (Sudoeste da área de estudo), que apresenta uma 
amplitude topográfica que varia entre 1000 e 2400 metros (na bacia), foram encontrados os maiores valores de precipitação, variando em torno de 1800 a 2400 mm. Esta área apesar de representar apenas $3 / 10$ de toda a bacia, corresponde a cerca de $32,56 \%$ da precipitação que ocorre na mesma, por favorecer a ocorrência de chuvas orográficas, ao constituir-se como uma barreira aos ventos úmidos vindos do oceano.

Em relação à cobertura que vem sendo dada a terra (mapa 5), cerca de $70 \%$ da bacia é caracterizada pela presença de agricultura e solo exposto. O intenso processo de uso que estas terras vêm passando, desde a retirada da vegetação nativa para ser usada para as lavouras, faz com que se observe na região um cenário de alteração e de significativa ação antrópica. Tais áreas são geralmente as menos elevadas, estão localizadas predominantemente a Sul e Leste da bacia e correspondem aos locais onde se registra as maiores temperaturas.

O que confirmou a hipótese de que a presença de vegetação e/ou corpos hídricos tenderia a diminuir a temperatura, uma vez que são reguladores hídricos e térmicos, enquanto que as superfícies desnudas ou urbanizadas (como a cidade de Juiz de Fora) ajudariam a reter calor e a aumentar as temperaturas, dado aos materias que as constituem. Na área de estudo, os resultados indicaram que as áreas com presença de vegetação e corpos hídricos apresentaram as menores temperaturas mais amenas $\left(14^{\circ}\right.$ e $\left.20^{\circ} \mathrm{C}\right)$, enquanto que sua inexistência foi caracterizada por áreas com temperaturas mais elevadas, podendo superar os $35^{\circ} \mathrm{C}$.

Porém, ressalta-se que é um quadro em transição, e acompanhando a própria história da ocupação humana, observa-se que novas (re)configurações espaciais vão se mostrando. 0 surgimento, por exemplo, de um grande número de propriedades que não atingiram sustento econômico, vem permitindo a retomada gradativa das coberturas florestais secundárias que hoje partilham do mosaico bastante diverso que compõe a bacia. O que poderá vir a ocasionar outras alterações microclimáticas.

Há ainda na bacia a presença de Unidades de Conservação (Parque Nacional do Itatiaia ICMBio e Parque Nacional da Serra do Ibitipoca - IEF) e corredores funcionais. Nesses, dada a junção de altitudes elevadas e presença de grandes áreas vegetadas, tem-se a formação 
de microclimas específicos, onde são encontradas baixas temperaturas. Também são registradas elevados totais de precipitação nesses locais.

É nos parques e serras, onde as coberturas vegetais do tipo mata se encontram em maior abundância, mas se considerada a distribuição espacial dessas e o tamanho da área de estudo, nota-se que estas são fragmentos e se localizaram geralmente nas áreas mais elevadas. As áreas mais densamente vegetadas coincidiram com aquelas onde ocorrem os maiores totais de precipitação, as menores temperaturas e a maior incidência de radiação.

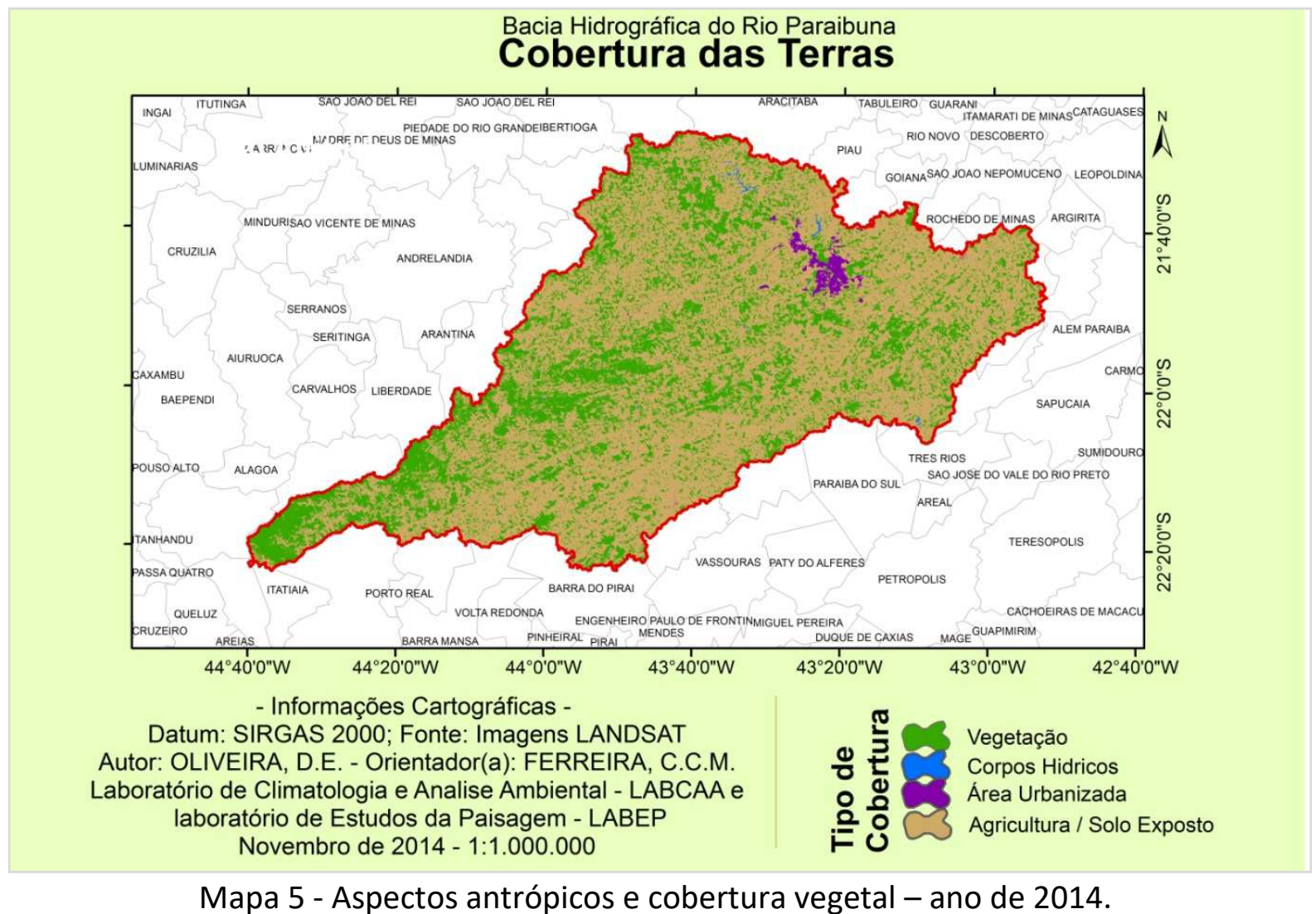

Após essa explanação acerca das relações entre os elementos climáticos e os fatores geográficos, nas três escalas de abordagem (zonal, regional e local) pode-se dizer que a bacia hidrográfica do rio Preto se mostrou como um sistema, onde os elementos se interligaram, formando arranjos específicos de interação atmosfera-ambiente, de modo que pôde ter seus atributos mapeados. E é neste contexto que o clima, se tornou passível de ser identificado, e para além da identificação, ter suas gêneses definidas. 
As inumeras relações existentes criaram arranjos especificos, os quais se materializando na paisagem, puderem ser indentificados. O zoneamento das tipologias climáticas demonstrou o quão complexa é a dinâmica climática e permitiu que se chega-se a uma síntese dos aspectos climáticos para a bacia do rio Preto. Foram encontradas três unidades climáticas principais (mapa 6).

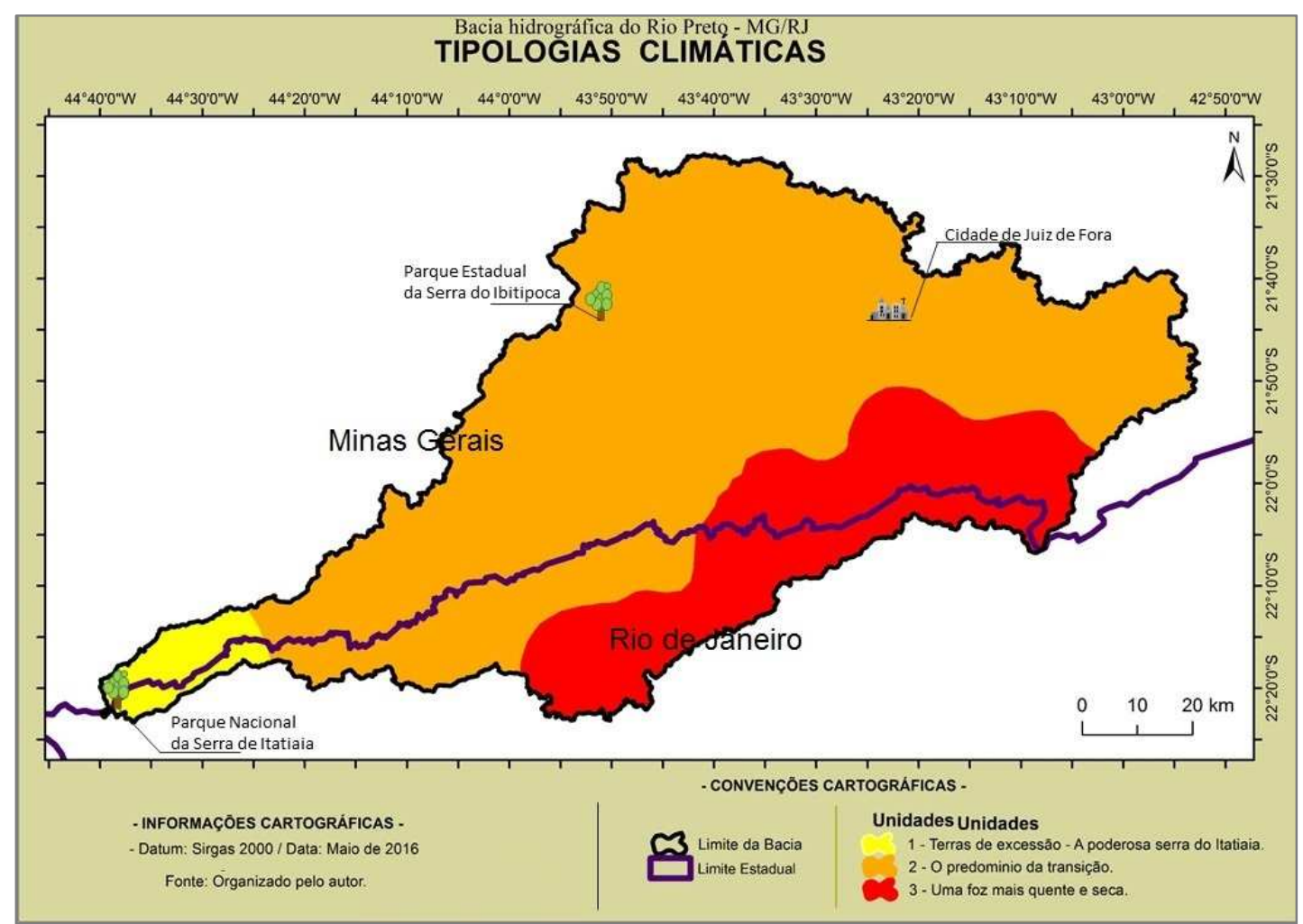

Mapa 6 - Principais unidades espaciais da climatologia da bacia do rio Preto - MG/RJ.

- $\quad$ Unidade 1 - Terras de exceção - A poderosa Serra do Itatiaia.

Localizada a Sudoeste da área de estudo encontra-se a Serra do Itatiaia, esta possui um altitude que pode chegar aos 2400 metros, uma amplitude topográfica de 1600 metros, e influencia diretamente para que se identifique um topoclima muito especifico na área de estudo. É esta o principal fator que diferencia a unidade 1 das demais, exercendo influencias principalmente na distribuição do fluxo de radiação e na formação de chuvas orográficas.

A unidade 1 é caracterizada por apresentar os maiores índices de precipitação (acima de $1800 \mathrm{~mm}$ ) e radiação (acima de $2000 \mathrm{Kwh} / \mathrm{m}^{2}$ ) e as menores temperaturas (menores que $18^{\circ} \mathrm{C}$ ) registrados na área de estudo. Foi a unidade que apresentou as características mais 
singulares em termos climáticos, o que está atrelado às próprias características do meio físico.

\section{- Unidade 2 - O predomínio da transição.}

Uma segunda unidade pode ser encontrada. Esta, mesmo sendo considerada uma área de transição entre os dois extremos que podem ser observados na área de estudo, é a que prevalece em termos de área, correspondendo a cerca de $60 \%$ da área de estudo.

É caracterizada por apresentar médios índices de precipitação, em torno dos 1000 a $1500 \mathrm{~mm}$, uma incidência de radiação por volta dos 700 a $1.800 \mathrm{Kwh} / \mathrm{m}^{2}$ e temperaturas elevadas, entre $30^{\circ} \mathrm{C}$ e $36^{\circ} \mathrm{C}$. É a unidade mais heterogênea em termos climáticos, dentre as três unidades encontradas.

- Unidade 3-Uma foz mais seca e quente.

Próximo à foz do rio Preto, e em grande parte das terras fluminenses presentes na bacia, pôde ser observada uma terceira unidade. Nesta, a baixa altitude (em torno dos 600 metros), atrelada a proximidade com a serra do Mar (mapa 1), acabou por ocasionar que fossem encontrados índices reduzidos de precipitação, chegando a um máximo de $1000 \mathrm{~mm}$, baixos valores de radiação (inferiores à $1.500 \mathrm{Kwh} / \mathrm{m}^{2}$ ) e temperaturas girando em torno dos $26^{\circ} \mathrm{C}$. É a cobertura da terra o principal fator de variação térmico dentro da unidade e a barreira orográfica dos compartimentos morfológicos mais elevados o que diferencia a precipitação e em alguns casos ao ocasionarem sombreamentos influenciam também a incidência de radiação.

\section{Considerações finais}

A bacia hidrográfica do rio Preto se mostrou como uma unidade sistêmica, onde climaambiente-sociedade criaram uma inteireza que pôde ser observada pelas manifestações climáticas. Radiação, temperatura e precipitação, foram elementos que permitiram observar, em um primeiro momento, a materialização de tais relações. Estes, atrelados aos 
sistemas atmofericos e o meio fisico local/regional deram indicaticos da dinâmica climática regional e permitiram que se chegasse a uma sintese climática regional.

A analise dos mapeamento e a identificação de tipologias climáticas permitiram afirmar que é o modelado do relevo o principal fator geográfico que influencia no clima local/regional na área de estudo. Este exerce influencias tanto sendo barreira como no direcionamento dos sistemas atmosféricos, com a formação ou não de chuvas orográficas, na caracterização de áreas sombreadas ou muito radiadas, e na formação de campos térmicos distintos. É elencando tais caracteristicas que a unidade climática mais singular encontrada na área de estudo (unidade 1) tem basicamente no relevo seu principal fator geografico de formação.

Os aportes metodológicos que foram utilizados, como o uso do SIG's e modelagens, e a base teórica consolidada, que é o trabalho de Nimer (1979), que desde a década de 70 já demonstrava a influência dos fatores geográficos na formação desse clima regional, permitiram com que se encontrasse resultados concisos e adaptados para a área de estudo. Também a escolha de trabalhar perpassando várias escalas espaciais contribuiu para uma visão totalitária e a metodologia indicada poderá ser adaptada em outras áreas, a fim de se reconhecer outras dinâmicas.

Mas se por um lado, este estudo apresentou algumas hipóteses do que justificaria a distribuição climática na bacia do Rio Preto, por outro, uma interpretação geográfica de tais informações levantadas, viria no sentido de diminuir os impactos que seus elementos apresentam sobre à sociedade. O fato de os elementos meteorológicos estarem diretamente ligados à vida das pessoas, pede que tal esfera seja melhor compreendida.

Os resultados obtidos contribuiram ao conhecimento da dinâmica climática na bacia hidrográfica do rio Preto, incetivando o resgaste dos estudos em escala regional, contribuindo para o (re)conhecimento da área de estudo, por meio da compreensão de sua organização espacial. 


\section{Referências bibliográficas}

ANA - Agência Nacional das Águas, 2013.

ARMANI, G.; Análise topo e microclimática tridimensional em uma microbacia hidrográfica de clima tropical úmido de altitude. Tese (Doutorado), São Paulo: USP, 2009.

AB'SÁBER, A. N.; Províncias geológicas e domínios morfoclimáticos no Brasil. São Paulo. Instituto de Geografia da USP - Geomorfologia, 1970. ISBN: 9788574805962.

ANTUNES, A.S.; Fenômenos de precipitação pluvial intensa: análise da espacialidade e variabilidade na bacia hidrográfica do rio Piracicaba-SP. Dissertação (Mestrado em Geografia - Geografia Física), São Paulo: USP, 2015.

BARBOSA J. P. M. Utilização de Método de Interpolação para Analise e Espacialização de Dados Climáticos: 0 SIG como Ferramenta. CAMINHOS DE GEOGRAFIA. v. 7, n. 17, 2006, pág: 85 - 96. Uberlandia. ISSN: 1678-6343.

BERTRAND, G.; Paisagem e geografia física global, esboço metodológico. Tradução de CRUZ. O.. São Paulo: Instituto de Geografia da USP, 1972.

CARVALHO, M. M. Clima urbano e vegetação: estudo analítico e prospectivo do Parque das Dunas de Natal. Dissertação (Mestrado), Natal: UFRN, 2001.

CAVALCANTI, I. F. A.; FERREIRA, N. J.; SILVA DIAS, M.A.F.; JUSTI DA SILVA, M. G. A. (Organizadores). Tempo e Clima no Brasil. São Paulo: Oficina de Textos, 2009. ISBN: 9788586238925.

CONTI, J. B.; O meio ambiente Tropical. IBGE - Geografia, v.14, n28. 1989.

CHRISTOFOLETTI, A. Modelagem de sistemas ambientais. São Paulo: Ed. Edgard Blücher Ltda, 1999. ISBN: 9788521201779.

ELY, D. F. Delineamentos teóricos-metodológicos da climatologia geográfica brasileira a partir da análise das teses e dissertações produzidas nos programas de pós-graduação em Geografia. In: SIMPÓSIO BRASILEIRO DE CLIMATOLOGIA GEOGRÁFICA, n. 17, Setembro de 2006. CD de Anais. Rondonópolis: UFMT.

FERREIRA, C.C.M., Zoneamento Agroclimático para implantação de sistemas agroflorestais com eucaliptos em Minas Gerais. Dissertação (Mestrado em meteorologia agricola), Viçosa: UFV, 1997.

FERREIRA, C. C. M. Tipos de tempo de categorias climáticas na Bacia do Rio Paraibuna-MG. Tese (Doutorado), São Paulo: USP, 2002.

FERREIRA, M.C.; Iniciação a analise geoespacial. São Paulo: UNESP, 2014. ISBN: 9788539305377.

FIALHO, E. S.; ALVES, R. S. ; ALVES, A. S.; Interações entre clima e sítio em situação sazonal de inverno: um estudo de caso em cidades da zona da mata mineira. Revista GeoNorte. v. 4, Edição Especial, 2012, pág: 916 931. Manaus. ISSN: 2237-1419.

PELLEGATTI, C. H. G. ; GALVANI, E.; Avaliação da precipitação no perfil Baixada Santista-Planície LitorâneaRebordo Interiorano da escarpa da serra do Mar-SP. In: Encontro de Geógrafos da América Latina, n. 12, Abril de 2009. CD de Anais. Montevideu: Uruguai. ISBN: 9789974819405.

PIMENTEL, F. O.; OLIVEIRA, D. E.; FERREIRA, C. C. M.; Relação entre o uso e ocupação da terra e a temperatura de superfície na Bacia do Alto Rio Grande, Sul de Minas Gerais. In XI Encontro da Ampege, n. 11, Outubro de 2015. CD de Anais. Presidente Prudente: UNESP. ISSN: 21758875.

IBGE - Instituto Brasileiro de Geografia e Estatistica, 2010.

LANG, BLASCHKE, S.; BLASCHKE, T. Análise da paisagem com SIG. São Paulo: Oficina de Texto, 2009. ISBN: 9788586238789

LOMBARDO, M. A.; O clima e a cidade. Boletim Climatológico. Ano 1, n.2. São Paulo: UNESP. 1996. 
MARCUZZO, F. F. N., GOULARTE, E. R., MELO, D. C. R., PINTO FILHO, R. F.; CARDOSO, M. R. D.; Mapeamento espacial, temporal e sazonal das chuvas no bioma Cerrado do estado do Tocantins. In: Simpósio Brasileiro de Sensoriamento Remoto, n. 15, Abril de 2011. CD de Anais. Curitiba. ISBN: 9788517000577.

MENDONÇA, F., DANNI-OLIVEIRA, I.M.; Climatologia, noções básicas e climas do Brasil. São Paulo: Oficina de Textos, 2007. ISBN: 9788586238543.

MELO JÚNIOR, J. C. F. Análise espaço-temporal do regime de chuvas na região hidrográfica do Atlântico, trecho Leste no Estado de Minas Gerais. Tese (Doutorado), Viçosa: UFV, 2003.

MONTEIRO, C. A. F.; A dinâmica climática e as chuvas do estado de São Paulo: estudo geográfico sob forma de atlas. São Paulo: IGEOG, 1973.

NIMER, E.; Climatologia do Brasil. Rio de Janeiro: Instituto Brasileiro de Geografia e Estatística, 1979. ISBN: 8524002824.

OLIVEIRA, D. E. ; FERREIRA. C.C.M.; Estimativa da distribuição do balanço de radiação global na bacia hidrográfica do rio Paraíbuna, MG/RJ, e suas correlações com atributos do meio físico. In: Semana de Geografia e Seminário da Pós-Graduação em Geografia, n. 15 e 2, Novembro de 2013. CD de Anais. Juiz de Fora: UFJF.

OLIVEIRA, D. E.; ASSIS, D. C.; FERREIRA, C. C. M.; Definição de unidades climáticas para a bacia hidrográfica do rio Paraibuna, MG/RJ. In: Simposio Brasileiro de Climatologia Geográfica, N. 11, Outubro de 2014. CD de Anais. Curitiba: UFPR.

OLIVEIRA, D. E.; ASSIS, D. C.; FERREIRA, C.C.M.; DISTRIBUIÇÃO ESPACIAL DA SAZONALIDADE NOS TIPOS DE TEMPO PARA A BACIA DO RIO PRETO, MG/RJ. In XI Encontro da Ampege, n. 11, Outubro de 2015. CD de Anais. Presidente Prudente: UNESP. ISSN: 21758875.

RIBEIRO, O.; Introdução ao Estudo da Geografia Regional. Lisboa: João Sá da Costa, 1995. ISBN: 9729230099.

SANT'ANNA NETO, J. L.; Decálogo da climatologia do sudeste brasileiro. Revista Brasileira de Climatologia. v. 1, 2005, pág: 43 - 60. Rio de Janeiro. ISSN: 2237-8642.

SANTOS, M.; A natureza do espaço. São Paulo: Hucitec, 1996. ISBN: 8531407133.

SILVA, C. A. S,; A variabilidade das chuvas na bacia do rio Corumbataí e implicações no consumo e na qualidade das águas do município de Rio Claro (SP). Dissertação (Mestrado em Geociências), Rio Claro: UNESP, 2001.

SILVA, C. A. S.; Distribuição temporo-espacial das chuvas na bacia do Corumbataí: variações ritmicas $e$ implicações no consumo e na qualidade das águas no município de Rio Claro (SP). Monografia, Rio Claro: UNESP, 1996.

SCHNEIDER, H.; A Geografia do clima da microrregião de Dourados (MS): regime e excepcionalidades pluviais no período de 1980 a 2012. Dissertação (Mestrado em Geografia), Dourados: UFGD, 2014.

SORRE, M.; Les Fondements de la Géographie Humaine. Tome Premier: Les fundaments biologiques. Paris: Armand. Colin, 1951.

TARIFA, J. R.; Os climas nos Maciços litorâneos da Juréia - Itatins: um ensaio de ritmanálise. Tese de livre docência, São Paulo: USP, 2002.

TAVARES, A.C.; Mudanças Climáticas. In GUERRA, A.J.T., VITTE, A.C. (Organizadores). Reflexões sobre a Geografia Física no Brasil. 1a Edição. Rio de Janeiro: Ed Bertrand Brasil. 2004. ISBN: 8528610497. 